\title{
The Role of Sport Marketing Mix in Generating Revenue for Iranian Football Clubs
}

\author{
${ }^{1}$ Jabar Seifpanahi Shabani*, ${ }^{1}$ Hassan Gharehkhani, ${ }^{1}$ Fakhrozaman Naderi \\ ${ }^{1}$ Department of Sport Sciences, Faculty of Humanities, University of Zanjan, Zanjan, Iran. ${ }^{2}$ Education Department, \\ Chaharmahal \& Bakhtiari, Iran.
}

\begin{abstract}
Background. Marketing mix is a tool which can be used by administrators to achieve their goals. Objectives. This research investigated the role of sports marketing mix in generating revenue for football clubs. Methods. Data for this mixed method research was obtained from library studies, interviews with experts, and questionnaires. The statistical population comprised employees of the Football Federation, football clubs, and universities in the field of sports marketing. Theoretical sampling was conducted in the qualitative stage and interviews continued to the point of saturation. The whole statistical population was sampled in the quantitative stage. Results. The results showed that each element of the sports marketing mix apart from price had a positive and significant impact on generating revenue for football clubs. Conclusion. Based on the importance and the role of sports marketing mix in generating revenue for football clubs, it is recommended that club managers strive to choose an appropriate marketing mix.
\end{abstract}

KEY WORDS: Marketing Plan, Price, Revenue, Managers.

\section{INTRODUCTION}

In today's competitive world, organizations need to use marketing techniques and specialized marketing research for their survival. Evaluations have shown that a lack of success originates from a company's inability to take advantage of marketing techniques. Such companies ignore market developments and the changing consumption patterns of customers and focus on selling instead of relying on advanced marketing; they choose profits over customer satisfaction. Marketing is a war, but not with guns. Rather, as Albert Emery says, "Marketing is a civilized war, and companies and organizations which use more favorable words, ideas, and intellectual discipline succeed in most of these battles. In other words, these companies and organizations must have updated and integrated marketing management in order to be successful in competition," (1). Pitts and Stotlear (2002) define sports marketing as "the process of planning and implementing activities for the production, pricing, promotion, and distribution of sports products to the needs or desires of customers and achieving a company's goals," (2).

Investment in international sports marketing around the world, for numerous companies and organizations which operate in the field of sports and focus on the world market, is a beginning to achieving economic and financial success. Global requests for sports goods have boosted the worth of the sports industry to an estimated $\$ 141$ billion. Moreover, sports offer a huge potential for

*. Corresponding Author: 
revenue generation on a global scale as a business for all parties involved. Sports have been increasingly commercialized and internationalized over the past decade. As a result, investments in sports marketing have begun (3). Among all sports, football had the greatest growth in the twentieth century (4), and a major share of the total sports industry is now allocated to it (5). Today, football is a market in which billions of dollars are invested. Extreme transfer costs, astronomical sums promised to sign football players, bickering and competition between sponsors to attract stars to promote and advertise their products, endless negotiations to acquire television rights, and the efforts of professional managers to find potential investors by making their team a model team are all only a part of today's football world (6).

Some results showed that football marketing has a significant and positive effect on economic boom. In other words, football marketing components such as the establishment of a central marketing system in football, brand advertising (internal and external), attraction of football stars by clubs, attraction of sponsors (internal and external), and enhancement of the quality and quantity of stadiums have the positive effect of increasing the country's football industry (7).

Clubs are trying to achieve the maximum revenue from their existing facilities because of the increased costs of sport clubs and intense competition to raise sport funds. However, most club managers must design their plans in an environment of declining revenues and increasing administrative costs (8). While selling stadium tickets was the main source of income for professional sports organizations in the early days, other sources of income such as business activities, financial and non-financial support, VIP areas, and television rights are far more important today (9).

Based on the findings, it can be argued that the privatization of football clubs facilitates advertisement and ticket sale revenues for the clubs (10).

While most football clubs around the world are well aware of the immense potential in the football industry and increase their revenue channels and methods each day, unfortunately, Iranian football clubs have acted very poorly in terms of revenue generation and are more of a consumer than a revenue generator. Clubs' neglect or lack of attention to marketing and revenue generation has a significant effect not only on their economic performance, but also on the technical quality of teams. Many studies have investigated the role and effect of marketing mix on consumer satisfaction, increased sales, market share, and greater consumption in different production and service industries, but no research on the effect of marketing mix on revenue generation in Iran's sports industry was found. Given the fact that the ultimate goal of most marketing activities is to earn more money, this study has tried to evaluate the effect of marketing mix elements on the revenue generation of football clubs. The main parts of all marketing activities are management and the selection of the right combination of elements in the marketing mix. Marketing mix is, in fact, a tool used by marketing managers to reach their goals and lead their organizations to achieve their determined goals. The famous marketing mix is the same $4 p$ which is more specific to manufacturing organizations. Given the fact that the $4 p$ mix does not work in service industries nor in an industry such as football in which the main product is a sports event, the $7 \mathrm{p}$ mix (product, price, place, promotion, people, physical evidence, and process) plus the protection factor which is very important in the football industry (Today, supporters of football are considered as partners because of their vital role in the success of the club.) are considered as $8 p$ in this research which evaluated the role and effect of these factors on revenue generation of football clubs. This research investigated the role of sports marketing mix in generating revenue for football clubs.

\section{MATERIALS AND METHODS}

Participants. The statistical population included three groups of CEOs and members of the marketing committees of 18 clubs in the Premier Football League of Iran, sports management professors at public universities throughout the country, and members of the Football Association Marketing Committee.

Sampling was done theoretically (targeted) in the step related to interviews, and interviews were continued to the point of saturation. A total of 15 interviews were conducted with 12 people. In the Delphi step, the identified factors were returned 
to those who were interviewed in the previous step in the form of a questionnaire so that factors could be screened and main and significant factors identified. The purposive sampling method was also used in this step, and the macrosampling method was used in the final step. The final questionnaires were distributed both in person and electronically. A total of 124 completed questionnaires were analyzed.

Methodology. The mixed sequential exploratory (qualitative - quantitative) method was used in this applied research. Theoretical studies and organized interviews were used to identify factors affecting the revenue generation of football clubs. The findings obtained from interviews and information gleaned from library studies were used to create a questionnaire with which to collect quantitative data.

Instrument. All factors affecting the revenue generation of football clubs which were identified from the literature and interviews were used to create a questionnaire regarding eight elements of the marketing mix (Product, Price, Place, Promotion, People, Protection, Physical evidence, and Process). Items on the questionnaire were rated on a five-point Likert scale; variables were evaluated in the ranges of 1 to 2.33 (undesirable), 2.34 to 3.66 (average), and 3.67 to 5 (desirable).

The validity of the questionnaire was evaluated by 10 professors of sports management and confirmed after some changes were made. Cronbach's alpha test was used to evaluate the reliability of the questionnaire. The reliability coefficients for different parts of the questionnaire are presented in Table 1.

Table 1. Cronbach's alpha coefficients for data collecting tools

\begin{tabular}{|c|c|c|c|}
\hline Questionnaire & & & $\begin{array}{l}\text { lity } \\
\text { ent }\end{array}$ \\
\hline \multirow{8}{*}{$\begin{array}{c}\text { Current status of marketing mix in Iranian clubs in Premier } \\
\text { Football League }\end{array}$} & Product & 0.95 & \multirow{8}{*}{0.99} \\
\hline & Price & 0.95 & \\
\hline & Place & 0.94 & \\
\hline & Promotion & 0.93 & \\
\hline & People & 0.90 & \\
\hline & Partnership & 0.92 & \\
\hline & Physical evidence & 0.94 & \\
\hline & Process & 0.95 & \\
\hline \multirow{8}{*}{$\begin{array}{l}\text { Importance of marketing mix elements on revenue generation of } \\
\text { football clubs }\end{array}$} & Product & 0.92 & \multirow{8}{*}{0.96} \\
\hline & Price & 0.89 & \\
\hline & Place & 0.83 & \\
\hline & Promotion & 0.90 & \\
\hline & People & 0.84 & \\
\hline & Partnership & 0.74 & \\
\hline & Physical evidence & 0.87 & \\
\hline & Process & 0.75 & \\
\hline
\end{tabular}

Data Collection. Data was collected from library studies (reviewing relevant domestic and foreign literature as well as documents and reports of domestic and foreign football clubs) and field methods (interviews and questionnaires).

Statistical Analysis. All factors affecting the revenue generation of football clubs which were identified from the literature and interviews were used to create a questionnaire regarding eight elements of the marketing mix. The questionnaire was used by experts to screen the identified factors using the Delphi technique, and the important factors were selected. Those factors agreed upon as important by the majority of experts were chosen. The final list of important factors was distributed to the statistical sample of this research in the form of the final 
questionnaire, and the importance of each factor was determined. The collected data was analyzed using the one-group t-test, dependent t-test, the Friedman test, and SPSS software.

\section{RESULTS}

Items on the questionnaire were rated on a five-point Likert scale; variables were evaluated in the ranges of 1 to 2.33 (undesirable), 2.33 to 3.66 (average) and 3.66 to 5 (desirable). Criteria receiving a score higher than 3.66 were considered as appropriate for evaluating the current status of the marketing mix in Iranian football clubs and the level of their importance in the revenue generation of football clubs. The results of onesample t-test of the evaluation of these elements are shown in Table 2. Based on the average scores of the elements and the results of onesample t-test, none of the statuses related to marketing mix elements were in the desirable range in Iranian football clubs, and their differences from 3.66 are significant $(\mathrm{p}=0.000)$. All eight elements had averages higher than 3.66, but the difference between the element of price and the 3.66 element of $t$ were not statistically significant $(\mathrm{p}=0.142)$.

Table 2. Results of one-sample t-test

\begin{tabular}{|c|c|c|c|c|c|c|}
\hline & \multirow[b]{2}{*}{$\begin{array}{l}\text { Elements of } \\
\text { marketing mix }\end{array}$} & \multicolumn{5}{|c|}{ Test value $=3.66$} \\
\hline & & Average & $\begin{array}{c}\text { Mean } \\
\text { differences }\end{array}$ & $\mathrm{t}$ & $\mathrm{df}$ & $\mathrm{p}$ \\
\hline \multirow{8}{*}{$\begin{array}{l}\text { Current status of marketing } \\
\text { mix in Iranian football clubs }\end{array}$} & Product & 2.28 & -1.37 & -18.63 & 123 & 0.000 \\
\hline & Price & 2.09 & -1.56 & -24.08 & 123 & 0.000 \\
\hline & Place & 2.29 & -1.36 & -17.30 & 123 & 0.000 \\
\hline & Promotion & 2.30 & -1.35 & -17.55 & 123 & 0.000 \\
\hline & People & 2.52 & -1.13 & -15.11 & 123 & 0.000 \\
\hline & Partnership & 2.19 & -1.46 & -19.51 & 123 & 0.000 \\
\hline & Physical evidence & 2.02 & -1.63 & -18.01 & 123 & 0.000 \\
\hline & Process & 2.08 & -1.57 & -19.17 & 123 & 0.000 \\
\hline \multirow{8}{*}{$\begin{array}{l}\text { Importance of marketing mix } \\
\text { elements on revenue } \\
\text { generation of football clubs }\end{array}$} & Product & 3.91 & 0.25 & 4.32 & 123 & 0.000 \\
\hline & Price & 3.75 & 0.09 & 1.47 & 123 & 0.142 \\
\hline & Place & 4.11 & 0.45 & 8.18 & 123 & 0.000 \\
\hline & Promotion & 3.81 & 0.15 & 2.03 & 123 & 0.044 \\
\hline & People & 4.09 & 0.43 & 7.54 & 123 & 0.000 \\
\hline & Partnership & 4.12 & 0.46 & 8.29 & 123 & 0.000 \\
\hline & Physical evidence & 4.07 & 0.41 & 7.02 & 123 & 0.000 \\
\hline & Process & 4.04 & 0.38 & 7.68 & 123 & 0.000 \\
\hline
\end{tabular}

The Friedman nonparametric test was used to rank the current status of marketing mix elements and their importance in revenue generation of Iranian football clubs. As shown in Table 3, rating differences are statistically significant $(\mathrm{p}=0.000)$. Findings showed that physical evidence has the most important element in revenue generation with an average rating of 5.54, but it has the worst rank in Iranian football clubs. Price has the worst rank in importance of marketing mix elements in revenue generation for football clubs with an average rating of 3.13 .

The dependent t-test was used to compare the current statuses of marketing mix elements and their importance in revenue generation in Iranian football clubs. As shown in Table 4, there were statistically significant differences among all eight marketing mix elements and their importance in revenue generation in Iranian football clubs $(\mathrm{p}<0.05)$.

Diagram 1 shows the current comparative status of the marketing mix elements in Iranian football clubs and their importance in revenue generation. The blue zone is related to marketing mix elements in Iranian football clubs, and the red zone shows the importance of marketing mix elements in the revenue generation of football clubs. As the diagram shows, the difference between these two is obvious. 
Table 3. Results of Friedman test

\begin{tabular}{|c|c|c|c|c|c|c|c|}
\hline & Variable & $\begin{array}{l}\text { Average } \\
\text { Rating }\end{array}$ & Rank & Chi square & $\mathrm{df}$ & $\mathrm{p}$ & $\mathrm{n}$ \\
\hline \multirow{8}{*}{$\begin{array}{l}\text { Current status of marketing } \\
\text { mix in Iranian football clubs }\end{array}$} & Physical evidence & 5.54 & 1 & \multirow{8}{*}{113.444} & \multirow{8}{*}{7} & \multirow{8}{*}{0.000} & \multirow{8}{*}{124} \\
\hline & Place & 5.41 & 2 & & & & \\
\hline & People & 4.92 & 3 & & & & \\
\hline & Partnership & 4.65 & 4 & & & & \\
\hline & Process & 4.38 & 5 & & & & \\
\hline & Promotion & 4.19 & 6 & & & & \\
\hline & Product & 3.79 & 7 & & & & \\
\hline & Price & 3.13 & 8 & & & & \\
\hline \multirow{8}{*}{$\begin{array}{l}\text { Importance of marketing mix } \\
\text { elements on revenue } \\
\text { generation of football clubs }\end{array}$} & People & 6.35 & 1 & \multirow{8}{*}{180.976} & \multirow{8}{*}{7} & \multirow{8}{*}{0.001} & \multirow{8}{*}{124} \\
\hline & Promotion & 5.12 & 2 & & & & \\
\hline & Place & 5.10 & 3 & & & & \\
\hline & Product & 4.93 & 4 & & & & \\
\hline & Partnership & 3.98 & 5 & & & & \\
\hline & Process & 3.88 & 6 & & & & \\
\hline & Price & 3.70 & 7 & & & & \\
\hline & Physical evidence & 2.95 & 8 & & & & \\
\hline
\end{tabular}

Table 4. Comparison of current statuses of marketing mix elements in Iranian football clubs and their importance in revenue generation

\begin{tabular}{ccccccc}
\hline Variable & $\begin{array}{c}\text { Average mix } \\
\text { elements in Iran }\end{array}$ & $\begin{array}{c}\text { Average importance } \\
\text { of mix elements }\end{array}$ & $\begin{array}{c}\text { Mean } \\
\text { differences }\end{array}$ & $\mathrm{t}$ & $\mathrm{df}$ & $\mathrm{p}$ \\
\hline Product & 2.28 & 3.91 & 1.63 & -29.763 & 123 & 0.000 \\
Price & 2.09 & 3.75 & 1.66 & -36.720 & 123 & 0.000 \\
Place & 2.29 & 4.11 & 1.82 & -31.408 & 123 & 0.000 \\
Promotion & 2.30 & 3.81 & 1.51 & -23.668 & 123 & 0.000 \\
People & 2.52 & 4.09 & 1.57 & -34.299 & 123 & 0.000 \\
Partnership & 2.19 & 4.12 & 1.93 & -29.545 & 123 & 0.000 \\
Physical evidence & 20.2 & 4.07 & 2.05 & -29.456 & 123 & 0.000 \\
Process & 2.08 & 4.04 & 1.96 & -29.876 & 123 & 0.000 \\
\hline
\end{tabular}

\section{DISCUSSION}

Marketing is related to social and human needs and meeting those needs. The decisionmaking process is very important in marketing management. This process is the same as the marketing management process and is always associated with it. Marketing managers must make decisions about the marketing mix elements they face in the decision-making process. Organizations must make timely decisions and have sufficient knowledge of the consumer and market needs so as to offer good products at reasonable prices. To do this, they must use appropriate methods of distribution, awareness campaigns, and a defined process with the help of efficient and responsible staff and base their decisions on customers' desires so as to increase their market share and keep their current customers with creativity, flexibility, and resources adapted to the needs and demands of internal and external customers $(11,12)$. 


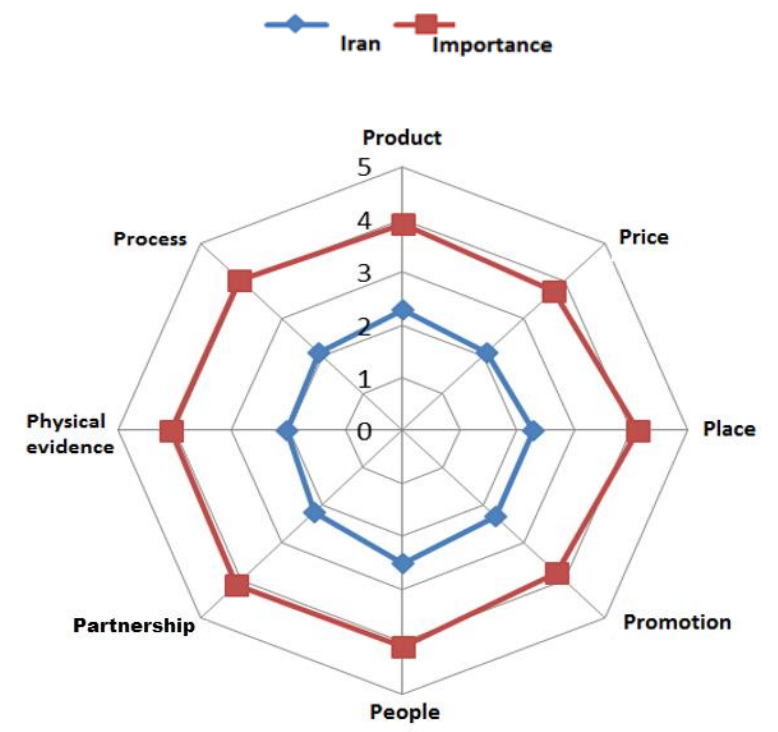

Diagram 1. Statuses of eight marketing mix elements

Many significant changes have taken place in football clubs over time to such an extent that the professional football of today cannot be compared to that of prior periods. Today, professional football has a court and area for a club, has experienced a comprehensive development in various fields, and has been organized in the form of a high-tech industry in association with other industries. Different evaluations and studies conducted in Iran have shown that currently, sports marketing in Iran is limited to the meager sale of tickets, sporting goods, some sports club merchandise, and the extremely meager sale of television rights. Globally, however, the football industry commands the largest share of the sports industry which itself is the world's sixth largest industry. Iran can also take effective steps to meet its potential capabilities. With this new approach, Iranian football clubs will be able to attract investment and enjoy revenue generation as a business enterprise in the future.

According to the findings of the current study, the status of the marketing mix in Iranian football clubs is not desirable. This result confirms the findings of Mohammad Kazemi et al. (2008), Elahi et al. (2009), and Vazir Zanjani et al. (2010) $(13,14,15)$. The lack of a desirable status of Iranian football clubs indicates that marketing activities in Iranian football clubs are based on tastes and are irregular. Physical evidence received the lowest ranking among marketing mix elements in Iranian football clubs. The criteria for measuring this element are related more to the quality and modernity of sports stadiums, and thus this ranking shows the clubs' lack of attention to this important and effective element in revenue generation. The element of pricing was ranked lowest after physical evidence, indicating the weakness of club policy regarding price determination for their products. Moreover, the weak rank and undesirable status of the process element indicates that there is no defined policy or procedure for the regular, quick, and easy provision of services and products. The element of people had the highest rank among the eight elements of marketing mix, even though it is similar to the other seven elements and is not an element that receives attention in Iranian football clubs. The items in this section of the questionnaire were designed to assess the ability of club employees and managers; perhaps club employees answered these questions with their own purposes in mind. Otherwise, the level of attention to this element in clubs can be much higher than the other elements; Iranian football clubs have fairly efficient, committed, motivated, and resourceful employees and managers.

The research findings also showed that the seven elements of product, promotion, physical evidence, processes, people, and protection have positive and significant effects on the revenue generation of football clubs. This finding is in 
line with the findings of Gholipour Soleimani (2009), Ramezanian et al. (2010), Fakhimi Azar et al. (2011), Aminbeidokhti et al. (2010), Vazir Zanjani et al. (2010), Kim and Hiyun (2011), and Sarker et al. (2012) $(16,17,18,19,20,21)$. Even though the mentioned studies did not evaluate the effect of these elements on revenue, their results showed that marketing mix elements affect customer satisfaction, increase purchases, influence purchasing decision-making, and increase sales. Clearly, these results lead to more revenue for the institution. It can be stated that this research is in line with the mentioned studies in terms of the positive effect the mentioned elements had on revenue generation. Based on the findings of the current research, the element of price has no significant effect on the revenue generation of football clubs. This finding is not in line with the findings of Gholipour Soleimani (2009), Ramezanian et al. (2010), Fakhimi Azar et al. (2011), Aminbeidokhti et al. (2010), Vazir Zanjani et al. (2010), and Kim and Hiyun (2011), all of which refer to the indirect effect of the price element in revenue generation. However, this finding is in line with those of Sarker et al. (2012) in this case $(16,17,18,19,20,21)$. Today, football clubs around the world do not just play football; rather, they are considered as business enterprises which have an annual turnover equaling millions of dollars. Thus, football clubs try to improve their standards to maintain their growth in the coming years. Sports organizations should have the ability to compete to achieve this goal, which is possible by using sports marketing achievements. Pitts and Stutler believe that sports marketing means using marketing mix variables for the creation of a relationship between interests of consumers of sports goods and services and supporters of sports organizations. Thus, all buyers and consumers of sports products will be affected by various elements of the marketing mix, and that will affect their composition and priority. Moreover, consumers' decisions depend on the type of product, its characteristics, and pricing practices and policies such as payment methods, distribution facilities, and procedures, promotions, and encouraging methods used by organizations.
Iranian football clubs can use the marketing mix as a framework and guide to strengthen their marketing activities and increase their revenue generation sources. The greatest level of effectiveness of marketing mix elements in revenue generation of football clubs is related to the element of physical evidence. The large difference between the current status of physical evidence in Iranian football clubs and the importance of this element in revenue generation, Iranian football clubs should pay more attention to this issue. The construction of new stadiums, renovation of existing stadiums, and consideration of facilities for the welfare of the spectators can greatly help increase the income of clubs. Banks and private investors can help clubs in constructing new stadiums. This is being done in countries such as Italy and the United Kingdom where clubs construct clubs using massive borrowings. Clubs can return these borrowings using the revenue generated by the stadium, especially on match days, and ultimately have a modern stadium.

\section{CONCLUSION}

The findings of the current research showed that the current situation of marketing mix elements considered in Iranian football clubs has a significant difference with the importance of these elements and their effect on revenue generation for football clubs. This shows that marketing in Iranian football clubs is more biased and irregular than scientific and based on the principles of marketing. Marketing principles and tools, including emphasis on marketing mix elements, can greatly help any organization, including football clubs.

\section{APPLICABLE REMARKS}

- Based on the importance and the role of sports marketing mix in generating revenue for football clubs, it is recommended that club managers strive to choose an appropriate marketing mix. 


\section{REFERENCES}

1. Constantinides E. Influencing the Online Consumer's Behavior: The Web Experience. Internet Research. 2004;14(2):111-126.

2- Pitss BG, Stotlar DK. Fundamentals of Sport Marketing. 2nd Edition. Sport Management Library. 2007; 417.

3- Vanessa R, Hamish R. International sport marketing: practical and future research implications. Journal of Business \& Industrial Marketing. 2011;26(8):614-620.

4- Poli R. Understanding globalization through football: The new international division of labor, migratory channels and transnational trade circuits. International Review for the Sociology of Sport. 2010;45(4):491-506.

5- Allmers S, Maennig W. Economic impacts of the FIFA Soccer World Cups in France 1998, Germany 2006, and outlook for South Africa 2010. Eastern Economic Journal. 2009;35(4):500-519.

6- Dimitropoulos P. The Financial Performance of the Greek Football Clubs, sport management international journal. 2010;6(1):1-28.

7- Homayounifar M, Pahlavan Mosaveri K, Shahriari E. Football Marketing and Its Effect on Economic Boom. Atlantic Review of Economics. 2014;2(2):1-26.

8- Jeffry DJ, Stephan DR. Comparing sport consumer motivations across multiple sports. Sport Marketing Quarterly. 2004;13(1):17-25.

9- Woratschek H, Schafmeister G. New Business Models for the Value Analysis of Sport Organizations. Universität Bayreuth. 2005;5(5)1-35.

10- Hemati-Nejad M, Goharrostami HR, Hosseini SS. Requirements for privatization of Iran pro league football clubs. Physical Education of Students. 2017;1(1):33-39.

11- Goi CL. A Review of Marketing Mix: 4Ps or More?. International Journal of Marketing Studies. 2009;1(1):1-14.

12- Pitss BG, Stotlar DK. Fundamentals of Sport Marketing”. Fitness Information Technology 3rd Ed, West Virginia University. 2007;417p.

13- Mohammad Kazemi R, Tondnevis F, Khabiri M. The comparison of "Price" element among marketing mix elements in the football pro- league of Iran. Journal of movement science \& sports. 2008;6(2):121-132 [Article in Farsi].

14- Elahi AR, Sajjadi N, Khabiri M, Abrishami H. Barriers to the Development of Revenues from Sponsorship in Iran Football Industry. Sport Management (Harakat). 2009;1(1):189-202 [Article in Farsi].

15- Vazir Zanjani, HR, Motmeni, AR, Mousavi Dlazyani H. Measuring Customer Satisfaction from marketing mix of services after sale in the heavy vehicles industry (Road transport). Business Studies. 2010;8(40):70-85 [Article in Farsi].

16- Gholipour A. Priority Setting to Influential Factors in the Hotel Management Industry Marketing with Emphasis on AHP Method (A Case Study: Guilan Province). Journal of Studies of Human Settlements Planning (JSHSP). 2009;4(8):157-178 [Article in Farsi].

17- Ramezanian MR, Esmaeilpour R, Tondkar H. Impact of Green Marketing Mix on Consumer Decision Making Process. Iranian Business Management. 2010;2(5):79-98 [Article in Farsi].

18- Fakhimi Azar S, Akbari Vaneabad M, Rasouli R. Investigating the Effect of Marketing Mix (4P) on the Sales Increase of Water heaters Produced by Ghaynar Khazar Company in Tabriz. Quarterly Journal of Productivity Management. 2011;4(16):79-106 [Article in Farsi].

19- Aminbeidokhti AA, Zargar SM, Nazari M. Strategic marketing mix to tourism industry. Journal of Strategic Management Studies. 2010;1(3):49-68 [Article in Farsi].

20- Kim JH, Hyun JY. A Model to Investigate the Influence of Marketing Mix Efforts and Corporate Image on Brand Equity in the IT Software Sector. Industrial Marketing Management. 2011;40(3):424-438.

21- Sarker MAH, Aimin W, Begum S. Investigating the Impact of Marketing Mix Elements on Tourists 'Satisfaction: An Empirical Study on East Lake. European Journal of Business and Management. 2012;4(7):273-282. 